\title{
DEFERENCE, THE UNIVERSE OF DISCOURSE, AND THE STANDARD OF REVIEW
}

\author{
RAJ SHARMA*
}

The author discusses an article written by Harry Arthurs which argues that lawyers and courts should attempt to curtail judicial review. The author's work focuses on Arthurs' term of art, "universe of discourse," and discusses its theoretical implications on Supreme Court of Canada judicial review jurisprudence. Additionally, the author addresses Arthurs' belief that the traditional role of the court system is dissimilar to that of administrative tribunals; as such, the courts should grant the utmost deference to decisions handed down by administrative tribunals. The author expands Arthurs' view by stating that tribunals are more concerned with policy implications while courts view themselves as the final arbiters of justice between the two parties.
L'auteur commente un article écrit par Harry Arthurs faisant valoir que les avocats et les tribunaux devraient essayer de freiner la révision judiciaire. L'auteur se concentre sur les termes techniques «univers du discours» d'Arthurs et en examine les implications théoriques sur la jurisprudence en matière de révision judiciaire de la Cour suprême du Canada. En outre, l'auteur aborde la croyance d'Arthurs que le rôle traditionnel des tribunaux judiciaires est différent de celui des tribunaux administratifs; à ce titre, les tribunaux judiciaires devraient accorder le plus grand respect aux décisions des tribunaux administratifs. L'auteur étoffe le point de vue d'Arthurs en disant que les tribunaux administratifs s'intéressent davantage aux implications de politique alors que les tribunaux judiciaires se considèrent comme les arbitres définitifs en matière de justice entre deux parties.

\section{TABLE OF CONTENTS}

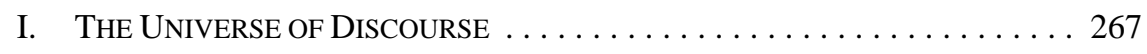

II. STANDARD OF REVIEW . . . . . . . . . . . . . . . . . . . . . . . . . . . . . 271

\section{THE UNIVERSE OF Discourse}

Twenty-five years ago, the inestimable Harry Arthurs did not (and likely still, does not) believe that judicial review is "natural, desirable, or inevitable," 1 and posited that the focus of lawyers and courts should not be to enhance judicial review, but to curtail it. ${ }^{2}$ In his view, lawyers and judges appear to suffer from a myopic court-centric view of the legal universe, much like those that lived before and during Galileo's lifetime, who felt that the sun revolved around the earth which was at the centre of the universe.

While the stakeholders previously mentioned may hold judicial review to be a second chance at justice - indeed, that was the theme of the conference Arthurs was to address and detailed in the above article - Arthurs could not disagree more, and advocated in his article that clients' interests were served best by securing justice in the first instance, rather than an

* $\quad$ LL.B., University of Alberta, currently completing LL.M., Osgoode Hall Law School. Prior to private practice, served as a Refugee Protection Officer, now termed a Tribunal Officer with the Immigration and Refugee Board. Currently sitting on the Law Society of Alberta's Continuing Professional Development Committee and the Legal Aid Society of Alberta's Regional Appeals Committee. He is also on the Board of Directors for Immigrant Services Calgary. His practice deals primarily in immigration law.

$1 \quad$ H.W. Arthurs, “Protection against Judicial Review”(1983) 43 R. du B. 277 at 277. Ibid. at 284 . 
after-the-fact application before a reviewing body that does not occupy the same "universe of discourse" 3 as the administrative tribunal that made the decision.

It is to this term of art, and its hypothetical implication on Supreme Court of Canada standard of review jurisprudence, that this article will concern itself. The article will first examine the merits of Arthurs' "universe of discourse" concept and consider the implications on standard of review jurisprudence (should it have been fully recognized and applied by the Supreme Court of Canada).

Arthurs, using an interesting analogy, charges the Supreme Court with guilt-free serial monogamy, moving from one "dalliance” (espousing a particular standard of review analysis) to the next. Even in 1983, some 25 years ago, Arthurs noted that there was "no unifying theme or logic in the Supreme Court's decisions." 4 In Arthurs' view, the survival of judicial review, notwithstanding the proliferation of privative clauses (intended by “naïve” legislators to curtail judicial review of administrative decisions) represented the court's "determination to retain some control over administrative decisions."5

In essence, the decision in Crevier v. Québec (A.G.), ${ }^{6}$ constitutionally entrenched judicial review - and Arthurs cannot hide his manifest disappointment. Arthurs, critical of the legal world view, proselytizes his own: judicial review should be limited and restrained — if not virtually abandoned. ${ }^{7}$ Judicial review is inimical to a proper understanding of the legal universe as a plurality - comprising the administrative and traditional court constellations, with neither taking precedence over the other.

Among his criticisms of judicial review is that the courts and tribunals "do not inhabit the same universe of discourse." A tribunal occupies a particular "universe of discourse" because of the monopoly it enjoys over resolving all disputes in their areas of delegated jurisdiction. The courts are thus naturally excluded $a b$ initio from the administrative regime that they are to review.

While the legislatures may have intended to create a decision-making apparatus with different values than that of the courts - views of justice by courts or judges "naturally tend to remain consistent with the assumptions of the system in which they continue to work." An example of divergent world views is the fact that institutional decision-making is wholly appropriate for administrative tribunals (assisting in consistency, coherence, and quality of decision making), but generally unthinkable for a court which is charged with administering justice to the specific parties before it. The Supreme Court, in both International Woodworkers of America, Local 2-69 v. Consolidated-Bathurst Packaging Ltd. ${ }^{10}$ and

\author{
Ibid. at 285. \\ Ibid. at 280 . \\ Ibid. \\ [1981] 2 S.C.R. 220. \\ Supra note 1 at 284. \\ Ibid. at 285. \\ Ibid. \\ [1990] 1 S.C.R. 282.
}


Tremblay v. Quebec (Commission des affaires sociales), ${ }^{11}$ recognized that administrative tribunal members seized of a decision "may quite properly be 'influenced' by the [policy] views" of other members. ${ }^{12}$

In his article, S. Ronald Ellis, ${ }^{13}$ maintains the disparate worlds of the courtroom and tribunal and warns against conflating the roles of administrative tribunal members and members of the judiciary. In this article, Ellis expresses his view that lifetime tenure of administrative tribunal members is incompatible with institutionalizing processes that are both legitimate and necessary. A tribunal is an administrative component of a statutory enterprise, which Ellis characterizes as the "institutional arrangements through which particular statutory rights are delivered."14 The tribunal has both a monopoly on the resolution of all disputes over rights emanating from the statutory enterprise and is constricted or specialized to the statutory enterprise. As a result, "not only the interests of individual parties but also the corporate interests of the tribunal - and of the enterprise,"15 are relevant, as opposed to trial court adjudication which, again, is restricted to the dispute and parties before it. Given the importance of the corporate interests, lifetime tenure would inhibit institutionalizing processes, as a tenured member would be immune to policy persuasion or other institutional guidance. The end result of this discussion is an illumination of the separation of the two legal worlds and an underscoring of Arthurs' assertion that judicial review by the legal courts is an alien exercise, bereft of the true understanding of the various influences, pressures, policy, and overall context within which administrative tribunals operate.

Continuing in this vein, and keeping in line with his views that the courts are naturally excluded from the universe occupied by the tribunal, it is instructive that Arthurs himself purposefully excluded participation of legal counsel who attempted to represent a party before Arthurs (who was at the time a sole arbitrator under a collective agreement for the men's clothing industry in Ontario). ${ }^{16}$ Arthurs had carefully crafted and zealously guarded his administrative kingdom and rejected legal representation in the vast majority of circumstances as inimical to the universe of discourse of that particular dispute resolution system.

The Ontario High Court of Justice, Divisional Court in Re Men's Clothing Manufacturers Association of Ontario and Arthurs ${ }^{17}$ disagreed when it dealt with a review of Arthurs decision to exclude the participation of legal counsel in Re Men's Clothing Manufacturers Association of Ontario and Toronto Joint Board, Amalgamated Clothing \& Textile Workers'

[1992] 1 S.C.R. 952.

See W. Ian C. Binnie \& Susan L. Gratton, “Institutional Decision-making: Did the Supreme Court Get it Right?” in Philip Anisman \& Robert F. Reid, eds., Administrative Law Issues and Practice (Toronto: Carswell, 1995) 147 at 150.

“Misconceiving Tribunal Members: Memorandum to Québec” (2005) 18 Can. J. Admin. L. \& Prac. 189. Ibid. at 192.

Ibid. at 200.

Re Men's Clothing Manufacturers Association of Ontario and Arthurs (1979), 26 O.R. (2d) 20 (H.C.J. (Div. Ct.)), aff'd Men's Clothing Manufacturers Association of Ontario v. Arthurs (1979), 12 C.P.C. 138.

Ibid. 
Union. ${ }^{18}$ As the Divisional Court noted at para. 13 of the decision, neither side in the industry had been represented by legal counsel throughout a history of 60 years. The unique nature of arbitration in the men's clothing industry was further underscored by the fact that Arthurs and his predecessor, Jacob Finkleman, had been permanent arbitrators since 1937, giving them undisturbed continuity, tradition, and insight — allowing them to proceed in a "very informal and expeditious manner, which has resulted in speedier and cheaper decisions than those in other industries ${ }^{\prime 19}$ - and of course contrasted with the function of the courts of law.

While finding in Re Men's Clothing that lawyers should not be excluded from the proceedings in all circumstances, Arthurs circumscribed the participation and intrusion of lawyers because:

\footnotetext{
For 60 years, the parties have been arbitrating with lay representatives only, to their apparent mutual satisfaction. Both the procedural and substantive aspects of industrial relationships throughout the industry seem to function well because they are unusually responsive to the special needs and traditions of the industry, rather than to the logic of legal analysis.
}

\begin{abstract}
The egregious introduction of lawyers may put all of this at risk: arranging arbitration dates to convenience counsel may well delay hearings; conventional techniques of proof may well lengthen them by many hours; legal arguments based on contract analysis may shift the arbitrator's attention from issues which the parties have hitherto expected him to consider and which need to be addressed if their relationship is to remain stable; and the cost of legal representation may generate such a deterrent to arbitration ... that processes of mutual adjustment break down because the wealthier party is effectively insulated from challenge. ${ }^{20}$
\end{abstract}

The traditional court system comprised of lawyers, courts, and judges on the one hand and administrative tribunals on the other, are from alternate or divergent realities, with differing perspectives and differing perceptions. Administrative tribunals are uniquely adapted to the "needs and traditions" of their particular enterprise where the "logic of legal analysis" "21 may be unhelpful and inappropriate. Courts and judges are simply removed from the "policy judgments and practical constraints" ${ }^{22}$ which drive the administrative tribunal and influence and shape their decisions and moreover, address the administrative decision "in virtual darkness. ${ }^{\text {23 }}$ The administrative tribunal itself is constrained and cannot participate, advocate, or educate the reviewing court.

Arthurs is correct in his characterization of courts and tribunals coming from different worlds. Tribunals, created on an ad hoc basis to deal with the delivery of policy can be clearly contrasted with the reviewing courts, seen by themselves and others as the final arbiters and deliverers of justice between parties. Arthurs' understanding is based on the belief that a pluralistic legal tradition supports a greater balance and has more stability and practicality than pursuing notions of all adjudication from a traditional court of law. While 
courts have admirable traits, they are wholly unsuited to meet the objectives which most administrative tribunals are charged to administer.

An analogy between administrative tribunals and the courts is a misconception. The administrative world involves a political process which forms its inception, ongoing policy considerations, and corporate mandates as a result of the policy. It takes place in largely informal settings set against the backdrop of the reality that there will never be sufficient resources to reach policy goals. It may involve administration and adjudication on a volume wholly unsuited to the courts of law. The administrative world view values participatory rights which would otherwise be excluded given the inhibitory financial costs and technical skill required to operate within the legal courts. Formal rules of procedure have the ability to alienate rather than incorporate, irrespective of the new direction that our society has taken with respect to efforts to improve access to justice.

\section{STANDARD OF REVIEW}

How would a standard of review analysis, incorporating Arthurs' term of art, impact on the (if not dysfunctional, far from desirable) relationship between administrative tribunals and reviewing courts?

Standard of review analysis has come a long way since the House of Lord's decision in Anisminic Ltd. v. Foreign Compensation Commission, ${ }^{24}$ which took a microscopic view of the delegate's actions to justify review. The landmark decision of Canadian Union of Public Employees Local 963 v. New Brunswick Liquor Corp. ${ }^{25}$ finally recognized and advocated a "deferential approach to the review of the administrative decision at hand."26

When a court looks to review an administrative tribunal's decision, the reviewing court must ascertain the extent of judicial review the legislature intended. The appropriate standard of review is ascertained by way of another term of art: the "pragmatic and functional" analysis. A reiteration of the four-part test is as follows:

(1) The presence or absence of a privative clause or a right of appeal;

(2) The relative expertise of the decision-maker and the reviewing court;

(3) The general purpose of the legislation authorizing the decision, and the purpose of any particular statutory provision that is at issue; and

(4) The nature of the problem being addressed by the decision-maker. ${ }^{27}$ presented at The Third Annual National Forum, Administrative Law \& Practice, Toronto, 24-25 September 2007) at 2.

Pushpanathan v. Canada (Minister of Citizenship and Immigration), [1998] 1 S.C.R. 982. 
Up until the recent Dunsmuir v. New Brunswick decision, ${ }^{28}$ the Supreme Court's decisions in Dr. Q v. College of Physicians and Surgeons of British Columbia ${ }^{29}$ and Law Society of New Brunswick v. Ryan ${ }^{30}$ indicated that there were only three recognized standards of review: (1) correctness; (2) reasonableness simpliciter; and (3) patent unreasonableness (with deference to the tribunal's decision increasing respectively along this continuum).

Had Arthurs' "universe of discourse” concept been adopted by the Supreme Court of Canada, the most immediate foreseeable impact on the "pragmatic and functional" test would be to skew the second factor to militate against judicial review and require much greater deference to the decision-maker of the first instance, acknowledging that the reviewing court is at arm's length from the intimate world of the administrative tribunal and its enabling or "home" statute. The tribunal has expertise and monopoly — specialized in rendering all adjudicative decisions in the statutory enterprise. The courts are merely and relatively strangers.

Assuming Arthurs' world view (or, perhaps more correctly, universe view) was adopted, there is no reason to presume that even statutory interpretation, traditional territory over which the courts reigned supreme, would be outside the purview of the tribunals (that is, even statutory interpretation by the tribunal should not attract greater judicial scrutiny). Philip Bryden would likely concur, given that he takes issue with the Supreme Court of Canada's conclusion that the "correctness" standard ${ }^{31}$ was appropriate to reviewing the decision in Monsanto Canada v. Ontario (Superintendent of Financial Services). ${ }^{32}$ Bryden finds that the conclusion is built around a number of assumptions that are "highly debatable." 33 One of the assumptions that Bryden finds questionable is that statutory interpretation fell within the bailiwick of the courts and that no deference was due to the impugned tribunal which was empowered with the actual administration and execution of the relevant statute. ${ }^{34}$

In my view, had Arthurs' "universe of discourse" concept been validated and accepted by this country's highest court, any standard of review analysis would enshrine deference to the tribunal in determining or interpreting its home statute (the statute which it was created and charged to administer), and the tribunal would also be immune from review unless a defect were immediate or obvious (the now defunct "patently unreasonable" standard of review). Justice Louis Lebel in his paper "Some Properly Deferential Thoughts on Deference" ${ }^{\text {"35 }}$ states that "[d]eference can be understood as the judicial response to the legislative choice to take a matter out of the hands of courts and put it primarily in the hands of a specialized tribunal." 36 Given that judges have little or no insight into policy, practical constraints, and

2008 SCC 9, [2008] 1 S.C.R. 190 [Dunsmuir].

2003 SCC 19, [2003] 1 S.C.R. 226.

2003 SCC 20, [2003] 1 S.C.R. 247.

See Philip Bryden, "Standards of Review and Sufficiency of Reasons: Some Practical Considerations" (2006) 19 Can. J. Admin. L. \& Prac. 191 at 198.

(2001), 198 D.L.R. (4th) 109.

Supra note 31 at 199.

Ibid. at 198.

(Paper presented to the Continuing Legal Education Society of British Columbia at the Administrative Law Conference, November 2007).

Ibid. at 0.0.2. 
other issues of substantive administrative law which inform administrative tribunals, why would it be natural or appropriate for the courts to divine the will of the legislature as set forth in the statute, granting no deference to the tribunal created for just that purpose - or lightly intrude on a matter the legislature has clearly placed within administrative responsibility?

As Arthurs so succinctly and eloquently states:

There is no reason to believe that a judge who reads a particular regulatory statute once in his life, perhaps in worse-case circumstances, can read it with greater fidelity to legislative purpose than an administrator who is sworn to uphold that purpose, who strives to do so daily, and is well-aware of the effect upon the purpose of the various alternate interpretations. ${ }^{37}$

The recent decision of the Supreme Court in Dunsmuir seems to indicate that reform of standard of review analysis is necessary:

The current approach to judicial review involves three standards of review, which range from correctness, where no deference is shown, to patent unreasonableness, which is most deferential to the decision maker, the standard of reasonableness simpliciter lying, theoretically, in the middle. In our view, it is necessary to reconsider both the number and definitions of the various standards of review, and the analytical process employed to determine which standard applies in a given situation. We conclude that there ought to be two standards of review - correctness and reasonableness. ${ }^{38}$

I do not believe that Dunsmuir is an innovation that evidences a convergence to Arthurs' position. This most recent pronouncement on judicial review and standards of review appears to be our highest courts' most recent infidelity (to use Arthurs own inimitable style) from the previous “dalliance” with a tripartite standard of review regime. However, the decision may in fact result in increased judicial review by eliminating the "patently unreasonable" standard which granted the greatest of deference to the administrative tribunal and required deference short of an absurd decision. Arguably, parties contemplating an action for judicial review could have been forestalled or intimidated by meeting the high threshold to establish that the decision was "patently unreasonable.” As it stands, any party contemplating judicial review may take heart in meeting only the threshold unreasonableness simpliciter - the previous middle ground between correctness and patent unreasonableness. That is not how the fivemember majority felt, however, indicating that merging the two deferential standards into "reasonableness" was not to be taken as an invitation for greater judicial scrutiny.

The Dunsmuir decision does not state in unequivocal language the need for the highest level of deference to the tribunal; nor does it subscribe to Arthurs' preference that justice should be obtained at the first instance.

Justice Lebel in his paper appears to foreshadow the decision in Dunsmuir, but does genuflect to the ideal posited by Arthurs: 
A South African jurist, Cora Hoexter offers a conceptualization of deference that is consistent with the notion of deference as respect...:

[A] judicial willingness to appreciate the legitimate and constitutionally-ordained province of administrative agencies; to admit the expertise of those agencies in policy-laden or polycentric issues; to accord their interpretations of fact and law due respect; and to be sensitive in general to the interests legitimately pursued by administrative bodies and the practical and financial constraints under which they operate. ${ }^{39}$

While the tripartite standard of review (and now a deceptively simple duality) was designed to differentiate and delineate between different forms of reviewable error, one questions whether the exercise has failed to recognize the fundamental question of whether deference can really be systematically categorized. In my opinion, and most unfortunately, a standard of review analysis and/or "deference" has more to do with the individual belief system of the reviewing justice than a cold, analytical, and almost surgical detachment in making a standard of review analysis (a term the Supreme Court now prefers over the phrase “pragmatic and functional approach”).

Justice Lebel makes a very Arthurs-like statement in his paper: "Our legal system, which I would describe as one of legal pluralism, is one that is only possible if judges adhere to a proper conception of deference and its role in judicial review." ${ }^{40}$

It is clear that if the Supreme Court had adopted Arthurs' "universe of discourse” the end result would be a standard of review analysis that begins and ends with deference and respect to the administrative tribunal charged with resolving all the rights disputes arising in a particular statutory enterprise (to use Ellis' terminology). An adoption of his term of art would have had a fundamental influence on standard of review analysis emphasizing the expertise of the tribunal and recognizing that expertise exists even on questions of statutory interpretation. Deference would be the byword because judges would understand that our present pluralistic legal system would not function very well with the intrusion of the courts into the fabric of the administrative world. In the end, adoption of Arthurs' term of art would result in the general acknowledgment that judicial review is an "exogenous and dysfunctional element” ${ }^{\text {41 }}$ in the administrative justice cosmos. 